\title{
Perbedaan konsumsi buah dan sayur pada anak sekolah dasar yang obes dan tidak obes di Kota Yogyakarta dan Kabupaten Bantul
}

Irma Nuraeni ${ }^{1}$, Hamam Hadi², Yhona Paratmanitya ${ }^{3}$

\begin{abstract}
Background: Curently, Indonesia has double burden problems nutrition, such as malnutrition and over nutrition. Overnutrition or obesity are not just happening in adults only, but also can occur in childhood. If the problem of obesity in children and adolescents cannot be resolved, it can be influenced obese in adulthood then potentially to have noncommunicable diseases, such as cardiovascular disease, hypertension and diabetes mellitus. Prevalence of obesity in children at Yogyakarta Province increases year by year (1;2). Obesity was caused by an imbalance in energy intake and energy expenditure. Children tend to consume high energy-dense, sweet taste meal, high fat foods and less dietary fiber from fruits and vegetables. Several studies showed that there was increasing in risk of obesity from someone who have less consumption of fruits and vegetables.

Objective: To determine differences in frequency and amount of fruit and vegetable consumption in elementary school children obese and non-obese at Yogyakarta Municipality and District of Bantul and to find out the risk of obesity in children who have less consumption of fruits and vegetables.

Methods: The study design was a case-control, 244 samples as cases (obese children) and 244 controls (non-obese children). The subject of this study was children aged 6-12 years who were seated in class 1 to class 5 elementary schools at Yogyakarta Municipality and District of Bantul. Identity data obtained from a structured questionnaire respondent, frequency and amount of fruit and vegetable consumption were taken from Semi Quantitative Food Frequency Questioner (SQFFQ). Then the results analyzed using statistical test.

Results: Statistical test showed that there were significant differences $(p<0,05)$ in the frequency and number of fruit and vegetable consumption in obese and non-obese elementary school children at Yogyakarta Municipality and District of Bantul. Multivariate analysis after controlled by gender and energy intake, showed that obese children who rarely consuming fruits ( $<7$ times/week) (OR=2,24, 95\% Cl: 1.53-3.28), rarely consuming vegetables ( $<7$ times/week) $(O R=2,52$, $95 \% \mathrm{Cl}: 1,70-3,73)$, and consuming fruits and vegetables less than 5 servings/day (equivalent to $400 \mathrm{~g} /$ day) $(O R=4,59$, 95\% Cl:2,11-10,00) were greater risk for being obesity.

Conclusion: Obese children had rarely and less consume of fruits and vegetables than that did in non-obese children at Yogyakarta Municipality and District of Bantul. The children rarely and less consuming fruits and vegetables increased the risk of obesity.
\end{abstract}

KEYWORDS: children obesity, vegetable, fruit

\begin{abstract}
ABSTRAK
Latar Belakang: Indonesia saat ini mengalami masalah gizi ganda, yaitu masalah gizi kurang dan gizi lebih. Kelebihan gizi atau obesitas pada anak dan remaja apabila tidak diatasi maka berdampak menjadi obesitas pada masa dewasa yang berpotensi mengalami penyakit tidak menular, seperti jantung, hipertensi dan diabetes mellitus. Prevalensi obesitas pada anak di Provinsi Daerah Istimewa Yogyakarta mengalami peningkatan dari tahun ke tahun (1; 2). Obesitas disebabkan ketidakseimbangan antara masukan dengan keluaran energi. Anak cenderung mengkonsumsi padat energi yang berasa manis dan berlemak tinggi serta makanan kurang serat dari buah dan sayur. Beberapa penelitian menunjukkan peningkatan risiko obesitas pada orang yang kurang konsumsi buah dan sayur.

Tujuan: Untuk mengetahui perbedaan frekuensi dan jumlah konsumsi buah dan sayur pada anak SD obes dan tidak obes di Kota Yogyakarta dan Kabupaten Bantul serta peran konsumsi buah dan sayur terhadap kejadian obesitas.

Metode: Rancangan penelitian ini adalah case-control, 244 kasus (anak obes) dan 244 kontrol (anak tidak obes). Subjek penelitian adalah anak usia 6-12 tahun yang duduk di kelas 1 hingga kelas 5 sekolah dasar di Kota Yogyakarta dan di Kabupaten Bantul. Data identitas diperoleh dari kuesioner terstruktur, sedangkan data frekuensi dan jumlah konsumsi buah dan sayur diperoleh dari semikuantitatif FFQ. Hasilnya kemudian dianalisis menggunakan uji statistik.
\end{abstract}

\footnotetext{
1 Program Studi IImu Kesehatan Masyarakat Fakultas Kedokteran UGM Yogyakarta, email: irma_nuraeni20@yahoo.com

2 Magister Gizi dan Kesehatan Fakultas Kedokteran Universitas Gadjah Mada, Jl.Farmako, Sekip Utara Yogyakarta 55281, email: hamamhadi99@ gmail.com

${ }^{3}$ STIKES Alma Ata Yogyakarta Prodi S1 Gizi, Jalan Ringroad Barat Daya No.1 Tamantirto, Yogyakarta, email: yhona_nitya@yahoo.com
} 


\begin{abstract}
Hasil: Pada anak SD obes dan tidak obes di Kota Yogyakarta dan Kabupaten Bantul terdapat perbedaan yang signifikan $(p<0,05)$ dalam frekuensi dan jumlah konsumsi buah dan sayur. Hasil analisis multivariat setelah dikontrol dengan jenis kelamin dan asupan energi menunjukkan bahwa anak SD obes yang mengkonsumsi buah jarang (< 7 kali/minggu) (OR=2,24, 95\% Cl:1,53-3,28), frekuensi konsumsi sayur jarang (<7 kali/minggu) (OR=2,52, 95\% Cl: 1,70-3,73), jumlah konsumsi buah dan sayur kurang dari 5 porsi/hari atau setara dengan 400 gr/hari (OR=4,59, 95\% Cl: 2, 11-10,00) berisiko lebih besar untuk terjadinya obesitas.

Kesimpulan: Anak SD yang obes lebih jarang dan lebih sedikit mengkonsumsi buah dan sayur dibandingkan dengan anak SD yang tidak obes di Kota Yogyakarta dan Kabupaten Bantul. Anak yang jarang dan sedikit mengkonsumsi buah dan sayur dapat meningkatkan risiko terjadinya obesitas.
\end{abstract}

KATA KUNCI: obesitas anak, sayur, buah

\section{PENDAHULUAN}

Indonesia saat ini mengalami masalah gizi ganda, yaitu masalah gizi kurang dan masalah gizi lebih. Kelebihan gizi yang menimbulkan kegemukan atau obesitas kini tidak hanya terjadi pada orang dewasa saja, namun juga dapat terjadi pada masa anak-anak (1). Apabila permasalahan obesitas pada anak dan remaja tidak diatasi, maka dapat berdampak pada masa dewasa yang berpotensi mengalami penyakit tidak menular, seperti jantung, hipertensi dan diabetes mellitus $(2,3)$.

Laporan Riskesdas tahun 2007 di Provinsi Daerah Istimewa (DI) Yogyakarta menunjukkan bahwa prevalensi berat badan lebih berdasarkan kategori IMT/U (Z score $>2$ ) pada anak usia 6-14 tahun adalah 7,6\% pada anak laki-laki dan 4,8\% pada anak perempuan (4). Laporan Riskesdas tahun 2010 menunjukkan bahwa prevalensi gemuk anak usia 6-12 tahun di Provinsi DI Yogyakarta adalah sebesar $7,8 \%$ (5).

Obesitas disebabkan oleh adanya ketidakseimbangan antara masukan energi dengan keluaran energi (6). Anak lebih menyukai jajan, makan dan minum padat energi yang berasa manis dan berlemak, serta makanan kurang serat dari buah dan sayur (7). Beberapa penelitian menunjukkan bahwa konsumsi buah dan sayur memiliki peran dalam mengontrol berat badan, seperti pada penelitian remaja di Brazil yang mengkonsumsi buah $\geq 5$ kali/minggu akan terproteksi 1,26 kali dari terjadinya overweight dan obesitas dibandingkan dengan yang konsumsi buah <5 kali/minggu (8). Begitu juga hasil penelitian orang dewasa di Brazil dengan mengkonsumsi buah kurang dari 1 kali sehari dapat berisiko 1,84 lebih besar untuk terjadinya overweight dan obesitas dibandingkan dengan yang mengkonsumsi lebih dari 1 hari sekali (9). Akan tetapi, di Indonesia perilaku kurang konsumsi buah dan sayur masih tinggi. Berdasarkan laporan Riskesdas 2007 menunjukkan bahwa perilaku kurang mengkonsumsi sayur dan atau buah ( $<5$ porsi/hari) pada penduduk umur 10 tahun ke atas di Provinsi Daerah Istimewa (DI) Yogyakarta sebanyak $86,1 \%(4)$.

Oleh karena tingginya prevalensi obesitas dan perilaku kurang konsumsi buah dan sayur di Provinsi DI Yogyakarta, maka peneliti merasa perlu untuk mengetahui ada tidaknya perbedaan frekuensi dan jumlah konsumsi buah dan sayur antara anak SD obes dan tidak obes di Kota Yogyakarta dan Kabupaten Bantul.

\section{BAHAN DAN METODE}

Metode penelitian ini adalah observasional, dengan rancangan case control. Penelitian ini dilaksanakan pada bulan Januari 2013 - Juni 2013 dan telah mendapatkan persetujuan serta kelaikan penelitian dari Komite Etik Fakultas Kedokteran UGM tanggal 3 April 2013 Ref: KE/ FK/325/EC.

Tahap pertama penelitian adalah survei skrining status gizi siswa SD kelas 1 hingga kelas 5 yang berusia 6-12 tahun di Kota Yogyakarta dan Kabupaten Bantul. Pengambilan sampel pada tahap skrining ini dengan metode probability proportional to size (PPS) (10). Unit dalam populasi sebagai klaster dalam penelitian ini adalah tingkatan kelas, kemudian menghitung interval sampling dengan membagi total populasi dengan jumlah klaster. Selanjutnya memilih 1 angka random sebagai titik awal permulaan pengambilan sampel. Klaster pertama adalah sekolah dasar tempat individu ke sekian ditemukan berdasarkan kolom populasi kumulatif, sedangkan pengambilan klaster selanjutnya dengan menambahkan secara kumulatif hingga klaster ke-35. Tahap selanjutnya adalah pengambilan sampel kasus kontrol dengan metode simple random sampling dengan kriteria kasus adalah anakanak yang teridentifikasi obesitas pada tahap skrining status gizi dan orangtua menyetujui informed consent, sedangkan kontrol diambil dari anak tidak obes dan overweight dari kelas dan sekolah yang sama dengan kasus tanpa melakukan matching terhadap jenis kelamin subjek.

Variabel terikat dalam penelitian ini adalah obesitas, dengan variabel bebas yang diteliti yaitu frekuensi konsumsi buah, frekuensi konsumsi sayur, serta jumlah konsumsi buah dan sayur anak SD, sedangkan variabel luar penelitian ini adalah status sosial ekonomi keluarga dan asupan energi.

Perhitungan status gizi diperoleh dengan menggunakan alat pengukur tinggi badan (TB) microtoise dan alat penimbangan berat badan (BB) timbangan digital dengan ketelitian $0,1 \mathrm{~kg}$. Status gizi berdasarkan indeks massa tubuh (IMT) yaitu berat badan (dalam kilogram) 
dibagi kuadrat tinggi badan (dalam meter) dengan cut off kurva rujukan WHO 2007 yang disesuaikan dengan umur anak (5-19 tahun) dan jenis kelamin (11). Anak mengalami obesitas jika IMT/umur $\geq$ persentil $95^{\text {th }}$, sedangkan tidak obesitas jika IMT/umur <persentil $95^{\text {th }}$. Frekuensi dan jumlah konsumsi buah dan sayur diukur dengan menggunakan semi quantitative food frequency questioner (SQFFQ) dalam kurun waktu konsumsi selama 3 bulan terakhir. Hasilnya dikategorikan menjadi jarang dan sering berdasarkan kali/minggu yang mendekati nilai median seluruh sampel. Jumlah konsumsi buah dan sayur dikategorikan menjadi $<5$ porsi/hari dan $\geq 5$ porsi/ hari. Penggunaan cut off 5 porsi/hari didasari rekomendasi WHO (World Health Organization) dan FAO (Food and Agriculture Organization) bahwa konsumsi buah dan sayur sedikitnya 400 gram setiap harinya atau setara dengan 5 porsi/hari agar terhindar dari obesitas $(12,13)$.

Asupan rata-rata zat gizi berupa asupan energi, protein, lemak, karbohidrat, serat, vitamin A dan vitamin $C$ yang diperoleh dari pengukuran total asupan makanan menggunakan SQFFQ. Asupan serat adalah jumlah serat yang diperoleh dari total asupan keseluruhan makanan dalam ukuran berat (gram) per hari. Asupan energi merupakan jumlah energi yang disumbangkan untuk kebutuhan tubuh anak yang dibandingkan dengan nilai Angka Kecukupan Gizi (AKG) rata-rata orang Indonesia sesuai kelompok umur, selanjutnya dikategorikan menjadi asupan energi tinggi dan cukup berdasar persen AKG. Sebelum SQFFQ ini digunakan dalam pengambilan data penelitian, kuesioner ini diujicobakan kepada anak sekolah dasar diluar populasi penelitian untuk mengetahui jenis buah dan sayur yang lazim dikonsumsi pada populasi tersebut. Selanjutnya dilakukan perbaikan dan penyesuaian kuesioner berdasarkan hasil temuan dalam ujicoba. Pegambilan data ini menggunakan bantuan food model. Data identitas dan karakteristik responden meliputi nama, umur, status sosial ekonomi orangtua, diperoleh dengan menggunakan kuesioner yang ditanyakan kepada ibu/wali siswa. Status sosial ekonomi merupakan keadaan yang menggambarkan sosial ekonomi keluarga yang dilihat dari tiga aspek, yaitu pendidikan terakhir, jenis pekerjaan, dan jumlah rata-rata pengeluaran rumah tangga.

Pengambilan data pengukuran berat badan dan tinggi badan, identitas dan karakteristik serta asupan makanan dilakukan oleh peneliti dibantu enumerator yang sebelumnya sudah diberikan pengarahan dan pelatihan, serta teknis pengumpulan data untuk menyamakan persepsi terhadap alat ukur yang digunakan dalam penelitian sehingga dapat menghindari dan meminimalkan tingkat kesalahan dalam pengukuran.

Data yang diperoleh kemudian diolah dan dianalisis menggunakan software WHO Anthroplus untuk menentukan status obesitas anak, sedangkan nilai asupan zat gizi diolah dengan menggunakan Nutrisurvey, selanjutnya dimasukan ke dalam program Epidata bersama karakteristik sampel dan variabel penelitian lainnya. Data kemudian dianalisis menggunakan uji statistik dengan menggunakan software STATA 11. Analisis univariat digunakan untuk melihat distribusi frekuensi karakteristik subjek penelitian. Analisis bivariat digunakan untuk melihat ada/tidaknya perbedaan karakteristik antara dua kelompok (kasus dan kontrol) dengan t-test dan Chi Square test, kemudian dianalisis regresi logistik sederhana untuk menentukan OR dari masing-masing variabel yang diduga sebagai faktor risiko terjadinya obesitas. Analisis multivariat digunakan untuk mencari variabel yang paling dominan berhubungan dengan obesitas pada subjek penelitian dengan uji regresi logistik berganda.

\section{HASIL}

Subjek dalam penelitian ini adalah anak sekolah dasar yang obes dan tidak obes di Kota Yogyakarta dan Kabupaten Bantul. Tabel 1 menggambarkan distribusi frekuensi karakteristik subjek penelitian secara rinci.

Subjek penelitian ini merupakan anak sekolah dasar berusia 6-12 tahun, kemudian dikelompokkan menjadi 6-9 tahun dan 10-12 tahun. Responden dengan kelompok usia 6-9 tahun berjumlah $274(56,14 \%)$ anak dan 10-12 tahun berjumlah $214(43,85 \%)$ anak. Penelitian ini juga didominasi dengan anak berjenis kelamin laki-laki sejumlah $56,56 \%$, sedangkan perempuan sebanyak $43,44 \%$. Sebagian besar orangtua subjek penelitian, baik ayah maupun ibu telah menempuh pendidikan formal. Sebanyak $43,44 \%$ ibu dari subjek penelitian, baik pada anak obes maupun tidak obes adalah ibu rumah tangga, sedangkan sisanya adalah ibu yang bekerja dengan jenis pekerjaan terbanyak adalah wiraswasta. Sebagian besar ayah dari subjek penelitian memiliki pekerjaan wiraswasta $(35,74 \%)$ dan hanya $0,83 \%$ di antaranya yang tidak bekerja. Mayoritas responden $(91,39 \%)$ memiliki orangtua dengan pengeluaran rumah tangga per bulan sebanyak lebih dari sama dengan Rp. 1.000.000.

Tabel 2 menunjukkan nilai rata-rata asupan zat gizi pada anak SD obes dan tidak obes di Kota Yogyakarta dan Kabupaten Bantul. Hasil uji t menunjukkan bahwa terdapat perbedaan yang signifikan pada asupan energi, lemak, karbohidrat, dan vitamin $C(p<0,05)$. Pada kelompok anak SD obes, asupan energi, protein, lemak, karbohidrat, dan vitamin A menunjukkan angka rata-rata lebih tinggi dibandingkan dengan anak tidak obes. Asupan protein, serat, dan vitamin A tidak terdapat perbedaan yang signifikan antara anak obes dan tidak obes $(p>0,05)$. Meskipun secara statistik tidak berbeda signifikan, anak SD yang obes memilki kecenderungan nilai rata-rata asupan serat dari total makanan yang dikonsumsi lebih rendah jika dibandingkan dengan asupan serat total pada anak SD yang tidak obes.

Rata-rata asupan serat buah dan sayur antara anak SD obes dan tidak obes berbeda signifikan $(p<0,05)$. 
Tabel 1. Karakteristik subjek penelitian anak sekolah dasar yang obes dan tidak obes di Kota Yogyakarta dan Kabupaten Bantul

\begin{tabular}{|c|c|c|c|}
\hline \multirow[b]{2}{*}{ Karakteristik } & \multicolumn{2}{|c|}{ Obesitas } & \multirow[b]{2}{*}{$\begin{array}{l}\text { Total } \\
\text { n (\%) }\end{array}$} \\
\hline & $\begin{array}{c}\text { Ya } \\
\mathrm{n}(\%)\end{array}$ & $\begin{array}{l}\text { Tidak } \\
\text { n (\%) }\end{array}$ & \\
\hline \multicolumn{4}{|l|}{ Kelompok usia } \\
\hline $6-9$ tahun & $138(56$ & $136(55,74)$ & 274 \\
\hline $10-1$ & & & \\
\hline \multicolumn{4}{|l|}{ Jenis kelamin } \\
\hline Laki-laki & $154(63$ & $122(50,00)$ & 276 \\
\hline Perempuan & $90(36,89)$ & $122(50,00)$ & 212 \\
\hline \multicolumn{4}{|l|}{ Pendidikan ibu } \\
\hline Tidak tamat SD & $2(0,82)$ & $0(0)$ & $2(0,41)$ \\
\hline Tamat SD/sederajat & $11(4,51)$ & $18(7,38)$ & $29(5,94)$ \\
\hline Tamat & $31(12,70)$ & $35(14,34)$ & $66(13,52)$ \\
\hline Tame & $101(41,39)$ & $102(41,80)$ & $203(41,60)$ \\
\hline Tamat Diplor & $99(40,57)$ & $89(36,48)$ & $188(38,52)$ \\
\hline \multicolumn{4}{|l|}{ Pekerjaan ibu } \\
\hline Buruh/buru & 10 & $13(5,33)$ & 23 \\
\hline ta & $31(12,70)$ & $32(13,11)$ & $63(12,91)$ \\
\hline PNS & $30(12,30)$ & $14(5,74)$ & $44(9,02)$ \\
\hline Wira & $64(26,23)$ & $57(23,36)$ & $121(24,80)$ \\
\hline Tida & $101(41,39)$ & $111(45,49)$ & $212(43,44)$ \\
\hline Lainnya & & $17(6,97)$ & \\
\hline \multicolumn{4}{|l|}{ Pendidikan ayah } \\
\hline Tidak tamat SD & $2(0,83$ & $0(0)$ & $2(0,41)$ \\
\hline Tam & & $11(4,55)$ & \\
\hline Tam & $25(10,33)$ & $33(13,64)$ & $58(11,98)$ \\
\hline Tam & $98(40,55)$ & $98(40,50)$ & $196(40,50)$ \\
\hline Tamat Diplom & $108(44,63)$ & $100(41,32)$ & $208(42,98)$ \\
\hline \multicolumn{4}{|l|}{ Pekerjaan ayah } \\
\hline $\begin{array}{l}\text { Petani/peternak/ } \\
\text { nelayan }\end{array}$ & $2(0,83)$ & $3(1,24)$ & $5(1,03)$ \\
\hline Buruh/buruh tani & $21(8,6$ & $36(14,88)$ & $57(11,78)$ \\
\hline Kary & $70(28$, & $71(29,34)$ & $141(29,13)$ \\
\hline POLRI & $39(16,12)$ & $31(12,81)$ & $70(14,46)$ \\
\hline Wiraswasta & $93(38,43)$ & $80(33,06)$ & $173(35,74)$ \\
\hline Tidak bekerja/IRT & $1(0,41)$ & $3(1,24)$ & $4(0,83)$ \\
\hline Lainnya & $16(6,61)$ & $18(7,44)$ & $34(7,02)$ \\
\hline \multicolumn{4}{|l|}{ Pengeluaran rumah } \\
\hline < Rp. 1.000 .000 & $224(91,80)$ & $222(90,98)$ & $446(91,39)$ \\
\hline$\geq$ Rp. 1.000 .000 & & & \\
\hline
\end{tabular}

Asupan serat dari buah dan sayur pada anak obes lebih sedikit jika dibandingkan dengan anak SD tidak obes (Tabel 3).

Rata-rata asupan serat buah dan sayur antara anak yang berusia 6-9 tahun dengan 10-12 tahun tidak berbeda signifikan $(p>0,05)$. Asupan serat dari buah dan sayur pada anak usia 10-12 tahun lebih banyak daripada anak usia 6-12 tahun (Tabel 4).

Rata-rata asupan serat buah dan sayur pada anak laki-laki tidak berbeda signifikan dibanding perempuan $(p>0,05)$. Kecenderungan asupan serat dari buah dan sayur pada anak perempuan lebih banyak daripada anak laki-laki (Tabel 5).

Hasil uji statistik gabungan di Kota Yogyakarta dan Kabupaten Bantul menunjukkan terdapat perbedaan signifikan antara anak sekolah dasar yang obes dengan anak yang tidak obes dalam hal jumlah dan frekuensi konsumsi buah dan sayur, begitu pula dengan jumlah total konsumsi buah dan sayur $(p<0,05)$. Pada anak sekolah dasar yang obes memilki rata-rata frekuensi dan jumlah konsumsi buah dan sayur lebih kecil dibandingkan dengan anak yang tidak obes (Tabel 6).

Hasil analisis bivariat menunjukkan tidak ada perbedaan yang signifikan pada variabel kelompok umur, pendidikan ibu, pekerjaan ibu, pendidikan ayah, pekerjaan ayah, pengeluaran rumah tangga, asupan serat total, dan frekuensi konsumsi jus $(p>0,05)$, sedangkan variabel jenis kelamin dan persentase asupan energi berdasar AKG terdapat perbedaan yang signifikan antara anak sekolah dasar yang obes dan tidak obes $(p<0,05)$. Pada variabel frekuensi konsumsi buah, frekuensi konsumsi sayur, dan jumlah konsumsi buah dan sayur terdapat hubungan yang signifikan dengan kejadian obesitas pada anak SD $(p<0,05)$. Anak SD yang jarang konsumsi buah ( $<7 \mathrm{kali} / \mathrm{ming} \mathrm{gu}$ ) memiliki peluang untuk menjadi obes sebesar 1,98 kali. Anak SD dengan frekuensi konsumsi sayur jarang ( $<7 \mathrm{kali} /$ minggu) mempunyai peluang 2,24 kali menjadi obes. Pada anak dengan jumlah konsumsi buah dan sayur kurang dari 5 porsi/hari mempunyai risiko menjadi obes sebesar 3,94 jika dibandingkan dengan anak

Tabel 2. Asupan zat gizi pada anak SD obes dan tidak obes di Kota Yogyakarta dan Kabupaten Bantul

\begin{tabular}{|c|c|c|c|c|}
\hline Asupan zat gizi/hari & $\begin{array}{c}\text { Anak SD obes } \\
\text { mean } \pm S D\end{array}$ & $\begin{array}{c}\text { Anak SD tidak obes } \\
\text { mean } \pm S D\end{array}$ & $\mathbf{t}$ & $\mathbf{p}$ \\
\hline Energi (kkal) & $2.199,55 \pm 758,37$ & $2.000,01 \pm 631,208$ & 3,1591 & $0,0008^{*}$ \\
\hline Protein $(\mathrm{g})$ & $67,19 \pm 2,15$ & $64,45 \pm 58,20$ & 0,6381 & 0,2618 \\
\hline Lemak (g) & $76,71 \pm 37,53$ & $66,33 \pm 25,66$ & 3,5682 & $0,0002^{*}$ \\
\hline Karbohidrat (g) & $323,79 \pm 158,37$ & $300,01 \pm 108,44$ & 1,9349 & $0,0268^{*}$ \\
\hline Serat $(g)$ & $13,47 \pm 20,61$ & $14,14 \pm 10,94$ & $-0,4495$ & 0,3266 \\
\hline Vitamin $A(\mu g)$ & $2.363,31 \pm 1.111,27$ & $2.272,16 \pm 1.088,21$ & 0,9154 & 0,8198 \\
\hline Vitamin C (mg) & $112,22 \pm 134,95$ & $143,46 \pm 213,59$ & $-1,9313$ & $0,0270^{*}$ \\
\hline
\end{tabular}

* Signifikan pada $p<0,05$ 
Tabel 3. Rata-rata asupan serat buah dan sayur pada anak SD obes dan tidak obes di Kota Yogyakarta dan Kabupaten Bantul

\begin{tabular}{lcccc}
\hline \multicolumn{1}{c}{ Asupan serat/hari } & $\begin{array}{c}\text { Anak SD obes } \\
\text { mean } \pm \text { SD }\end{array}$ & $\begin{array}{c}\text { Anak SD tidak obes } \\
\text { mean } \pm \text { SD }\end{array}$ & t & p \\
\hline Serat dari buah $(\mathrm{g})$ & $2,05 \pm 2,08$ & $3,45 \pm 5,57$ & $-3,4549$ & $0,0001^{*}$ \\
Serat dari sayur $(\mathrm{g})$ & $1,11 \pm 1,06$ & $1,98 \pm 2,25$ & $-5,4751$ & $0,0000^{*}$ \\
Serat dari buah dan sayur $(\mathrm{g})$ & $3,16 \pm 2,47$ & $5,43 \pm 6.16$ & -5.3262 & $0,0000^{*}$ \\
\hline
\end{tabular}

* Signifikan pada $p<0,05$

Tabel 4. Rata-rata asupan serat dari buah dan sayur pada anak SD berdasarkan kelompok umur di Kota Yogyakarta dan Kabupaten Bantul

\begin{tabular}{lcccc}
\hline \multicolumn{1}{c}{ Asupan serat/hari } & $\begin{array}{c}\mathbf{6 - 9} \text { tahun } \\
\text { mean } \pm \text { SD }\end{array}$ & $\begin{array}{c}\mathbf{1 0 - 1 2} \text { tahun } \\
\text { mean } \pm \text { SD }\end{array}$ & $\mathbf{t}$ & $\mathbf{p}$ \\
\hline Serat dari buah $(\mathrm{g})$ & $2,62 \pm 4,77$ & $2,92 \pm 3,50$ & $-0,7545$ & 0,4509 \\
Serat dari sayur $(\mathrm{g})$ & $1.46 \pm 1.63$ & $1,65 \pm 2,02$ & $-1,1269$ & 0,2603 \\
Serat dari buah dan sayur $(\mathrm{g})$ & $4.08 \pm 5,14$ & $4,57 \pm 4.38$ & -1.0894 & 0,2765 \\
\hline
\end{tabular}

* Signifikan pada $p<0,05$

Tabel 5. Rata-rata asupan serat dari buah dan sayur pada anak SD berdasarkan jenis kelamin di Kota Yogyakarta dan Kabupaten Bantul

\begin{tabular}{lcccc}
\hline \multicolumn{1}{c}{ Asupan serat/hari } & $\begin{array}{c}\text { Laki-laki } \\
\text { mean } \pm \text { SD }\end{array}$ & $\begin{array}{c}\text { Perempuan } \\
\text { mean } \pm \text { SD }\end{array}$ & t & p \\
\hline Serat dari buah $(\mathrm{g})$ & $2,58 \pm 3,57$ & $2,98 \pm 5,02$ & $-1,0282$ & 0,3044 \\
Serat dari sayur $(\mathrm{g})$ & $1,40 \pm 2,09$ & $1,75 \pm 2,09$ & $-1,9600$ & 0,0506 \\
Serat dari buah dan sayur $(\mathrm{g})$ & $3,98 \pm 4,10$ & $4,70 \pm 5.61$ & -1.6440 & 0,1008 \\
\hline
\end{tabular}

* Signifikan pada $p<0,05$

Tabel 6. Perbedaan rata-rata frekuensi dan jumlah konsumsi buah dan sayur antara kasus dengan kontrol di Kota Yogyakarta dan Kabupaten Bantul

\begin{tabular}{lcccc}
\hline \multicolumn{1}{c}{ Variabel } & $\begin{array}{c}\text { Kasus } \\
\text { mean } \pm \text { SD }\end{array}$ & $\begin{array}{c}\text { Kontrol } \\
\text { mean } \pm \text { SD }\end{array}$ & t & p \\
\hline Jumlah konsumsi buah (porsi/hari) & $1,33 \pm 1,42$ & $1,83 \pm 2,06$ & $-3,1192$ & $0,0010^{*}$ \\
Frekuensi konsumsi buah (kali/minggu) & $6,76 \pm 6,46$ & $9,22 \pm 9,18$ & $-3,4302$ & $0,0003^{*}$ \\
Jumlah konsumsi sayur (porsi/hari) & $0,62 \pm 0,53$ & $1,06 \pm 1,13$ & $-5,4650$ & $0,0000^{*}$ \\
Frekuensi konsumsi sayur (kali/minggu) & $9,99 \pm 9,51$ & $14,21 \pm 13,74$ & $-3,9419$ & $0,0000^{*}$ \\
Jumlah total konsumsi buah dan sayur (porsi/hari) & $1,96 \pm 1,62$ & $2,89 \pm 2,54$ & $-4,8609$ & $0,0000^{*}$ \\
\hline
\end{tabular}

* Signifikan pada $p<0,05$

yang konsumsi buah dan sayurnya lebih dari 5 porsi/hari (Tabel 7).

Hasil analisis bivariat (Tabel 7) kemudian dianalisis multivariat dengan menggunakan regresi logistik berganda. Analisis multivariat ini digunakan untuk menganalisis hubungan variabel obesitas (terikat) dengan variabel frekuensi dan jumlah konsumsi buah dan sayur (bebas) dan beberapa faktor luar yang berhubungan (covariates). Analisis yang digunakan adalah regresi logistik ganda dengan model faktor risiko pada tingkat kepercayaan (confidence interval) $95 \%$.

Hasil analisis multivariat setelah dikontrol dengan variabel jenis kelamin dan persentase asupan energi berdasar AKG, maka variabel yang berisiko terhadap obesitas adalah frekuensi jarang konsumsi buah $(<7$ kali/ minggu), frekuensi jarang konsumsi sayur ( $<7$ kali/ minggu), dan kurang mengkonsumsi buah dan sayur $(<5$ porsi/hari). Pada model 1 menunjukkan bahwa frekuensi jarang konsumsi buah ( $<7 \mathrm{kali} /$ minggu) berisiko 2,24 kali untuk terjadinya obesitas. Pada model 2, anak SD yang jarang mengkonsumsi sayur ( $<7 \mathrm{kali} / \mathrm{minggu}$ ) berisiko 2,52 kali untuk terjadinya obesitas jika dibandingkan dengan anak SD yang sering mengkonsumsi sayur ( $\geq 7 \mathrm{kali} / \mathrm{ming} \mathrm{gu}$ ). Hal ini berarti semakin jarang frekuensi konsumsi buah dan sayur, maka semakin tinggi risiko untuk terjadinya obesitas. Pada model 3, anak SD yang mengkonsumsi buah dan sayur kurang dari 5 porsi/hari berisiko menjadi obes sebesar 4,59 kali dibandingkan dengan anak SD yang mengkonsumsi buah dan sayur lebih dari 5 porsi/hari (Tabel 8).

Gambar 1 dan Gambar 2 menunjukkan dosis respon frekuensi konsumsi sayur terhadap kejadian obesitas 
Tabel 7. Analisis bivariat antara variabel terikat (obesitas) dengan variabel bebas

\begin{tabular}{|c|c|c|c|c|c|c|c|}
\hline \multirow{3}{*}{ Variabel } & \multicolumn{4}{|c|}{ Obesitas } & \multirow{3}{*}{$\chi^{2}$} & \multirow{3}{*}{$\begin{array}{c}\text { Crude OR } \\
\text { (COR) }\end{array}$} & \multirow{3}{*}{ p-value } \\
\hline & \multicolumn{2}{|c|}{ Ya } & \multicolumn{2}{|c|}{ Tidak } & & & \\
\hline & $n=244$ & $\%$ & $\mathrm{n}=\mathbf{2 4 4}$ & $\%$ & & & \\
\hline \multicolumn{8}{|l|}{ Usia } \\
\hline $6-9$ tahun & 138 & 50,36 & 136 & 49,64 & & 1,00 & (ref) \\
\hline 10-12 tahun & 106 & 49,53 & 108 & 50,47 & 0,03 & 0,97 & 0,855 \\
\hline \multicolumn{8}{|l|}{ Jenis kelamin } \\
\hline Laki-laki & 154 & 55,80 & 122 & 44,20 & \multirow[t]{2}{*}{8,54} & 1,71 & \multirow{2}{*}{$\begin{array}{c}0,003^{*} \\
\text { (ref) }\end{array}$} \\
\hline Perempuan & 90 & 42,45 & 122 & 57,55 & & 1,00 & \\
\hline \multicolumn{8}{|l|}{ Pendidikan ibu } \\
\hline Rendah (< tamat SLTA) & 44 & 45,36 & 53 & 54,64 & \multirow[t]{2}{*}{1,04} & 0,79 & \multirow{2}{*}{$\begin{array}{c}0,307 \\
\text { (ref) }\end{array}$} \\
\hline Tinggi ( $\geq$ tamat SLTA) & 200 & 51,15 & 191 & 48,85 & & 1,00 & \\
\hline \multicolumn{8}{|l|}{ Pekerjaan ibu } \\
\hline Bekerja & 143 & 51,81 & 133 & 48,19 & \multirow[t]{2}{*}{0,83} & 1,18 & \multirow{2}{*}{$\begin{array}{c}0,361 \\
\text { (ref) }\end{array}$} \\
\hline Tidak bekerja/IRT & 101 & 47,64 & 111 & 52,36 & & 1,00 & \\
\hline \multicolumn{8}{|l|}{ Pendidikan ayah } \\
\hline Rendah (< tamat SLTA) & 36 & 45,00 & 44 & 55,00 & \multirow[t]{2}{*}{0,96} & 0,79 & \multirow{2}{*}{$\begin{array}{c}0,327 \\
\text { (ref) }\end{array}$} \\
\hline Tinggi ( $\geq$ tamat SLTA) & 208 & 50,98 & 200 & 49,02 & & 1,00 & \\
\hline \multicolumn{8}{|l|}{ Pekerjaan ayah } \\
\hline Bekerja & 243 & 50,21 & 241 & 49,79 & \multirow[t]{2}{*}{1,01} & 3,02 & 0,304 \\
\hline Tidak bekerja & 1 & 25,00 & 3 & 75,00 & & 1,00 & (ref) \\
\hline \multicolumn{8}{|l|}{ Pengeluaran rumah tangga } \\
\hline < Rp.1.000.000 & 20 & 47,62 & 22 & 52,38 & \multirow[t]{2}{*}{0,10} & 0,90 & 0,746 \\
\hline$\geq$ Rp. 1.000 .000 & 224 & 50,22 & 222 & 49,78 & & 1,00 & (ref) \\
\hline Asupan energi & & & & & & & \\
\hline Tinggi $\geq 110 \%$ AKG & 128 & 56,39 & 99 & 43,61 & 6,93 & 1,62 & $0,008^{*}$ \\
\hline Cukup $<110 \%$ AKG & 116 & 44,44 & 145 & 55,56 & & 1,00 & (ref) \\
\hline Frekuensi konsumsi buah (k & & & & & & & \\
\hline Jarang $<7$ & 150 & 57,92 & 109 & 42,28 & 13,83 & 1,98 & $0,000^{*}$ \\
\hline Sering $\geq 7$ & 94 & 41,05 & 135 & 58,95 & & 1,00 & (ref) \\
\hline Frekuensi konsumsi sayur ( & & & & & & & \\
\hline Jarang $<7$ & 112 & 62,57 & 67 & 37,43 & 17,86 & 2,24 & $0,000^{*}$ \\
\hline Sering $\geq 7$ & 132 & 42,72 & 177 & 57,28 & & 1,00 & (ref) \\
\hline Jumlah konsumsi buah dan & & & & & & & \\
\hline$<5$ & 235 & 52,57 & 212 & 47,43 & 14,08 & 3,94 & $0,000^{*}$ \\
\hline$\geq 5$ & 9 & 21,95 & 32 & 78,05 & & 1,00 & (ref) \\
\hline Jumlah asupan serat total $(\mathrm{g}$ & & & & & & & \\
\hline$<20$ & 219 & 51,53 & 206 & 48,47 & 3,08 & 1,61 & 0,079 \\
\hline$\geq 20$ & 25 & 39,68 & 38 & 60,32 & & 1,00 & (ref) \\
\hline Frekuensi konsumsi jus (kali & & & & & & & \\
\hline Jarang $<1$ & 73 & 48,99 & 76 & 51,01 & 0,08 & 0,94 & 0,768 \\
\hline Sering $\geq 1$ & 171 & 50,44 & 168 & 49,56 & & 1,00 & (ref) \\
\hline
\end{tabular}

* Signifikan pada $p<0,05$

Tabel 8. Permodelan multivariat analisis regresi logistik (variabel terikat: obesitas)

\begin{tabular}{|c|c|c|c|}
\hline Variabel & $\begin{array}{c}\text { Model } 1 \\
\text { OR }\end{array}$ & $\begin{array}{c}\text { Model } 2 \\
\text { OR }\end{array}$ & $\begin{array}{c}\text { Model } 3 \\
\text { OR }\end{array}$ \\
\hline Frekuensi konsumsi buah jarang ( $<7$ kali/ minggu) & $\begin{array}{c}2,24 \\
(1,53-3,28)\end{array}$ & - & - \\
\hline Frekuensi konsumsi sayur jarang ( $<7$ kali/ minggu) & - & $\begin{array}{c}2,52 \\
(1,70-3,73)\end{array}$ & - \\
\hline Jumlah konsumsi buah dan sayur ( $<5$ porsi/hari) & - & - & $\begin{array}{c}4,59 \\
(2,11-10,00)\end{array}$ \\
\hline Asupan energi tinggi ( $\geq 110 \%$ AKG) & $\begin{array}{c}1,87 \\
(1,28-2,77)\end{array}$ & $\begin{array}{c}1,83 \\
(1,25-2,67)\end{array}$ & $\begin{array}{c}1,75 \\
(1,21-2,54)\end{array}$ \\
\hline $\begin{array}{l}\text { Jenis kelamin } \\
\text { Laki-laki }\end{array}$ & $\begin{array}{c}1,64 \\
(1,13-2,37)\end{array}$ & $\begin{array}{c}1,69 \\
(1,16-2,45)\end{array}$ & $\begin{array}{c}1,68 \\
(1,16-2,44)\end{array}$ \\
\hline Log likelihood & $-321,93$ & $-319,86$ & $-322,02$ \\
\hline Pseudo $\mathrm{R}^{2}$ & 0,048 & 0,054 & 0,048 \\
\hline
\end{tabular}




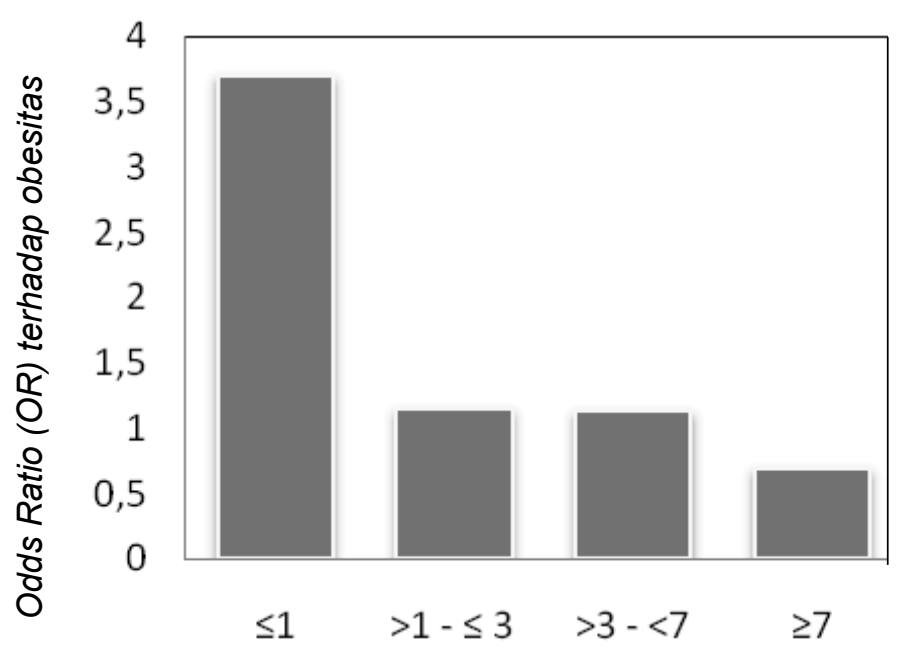

Frekuensi konsumsi buah (kali/minggu)

Gambar 1. Dosis respon frekuensi konsumsi buah terhadap kejadian obesitas pada anak obes dan tidak obes di Kota Yogyakarta dan Kabupaten Bantul

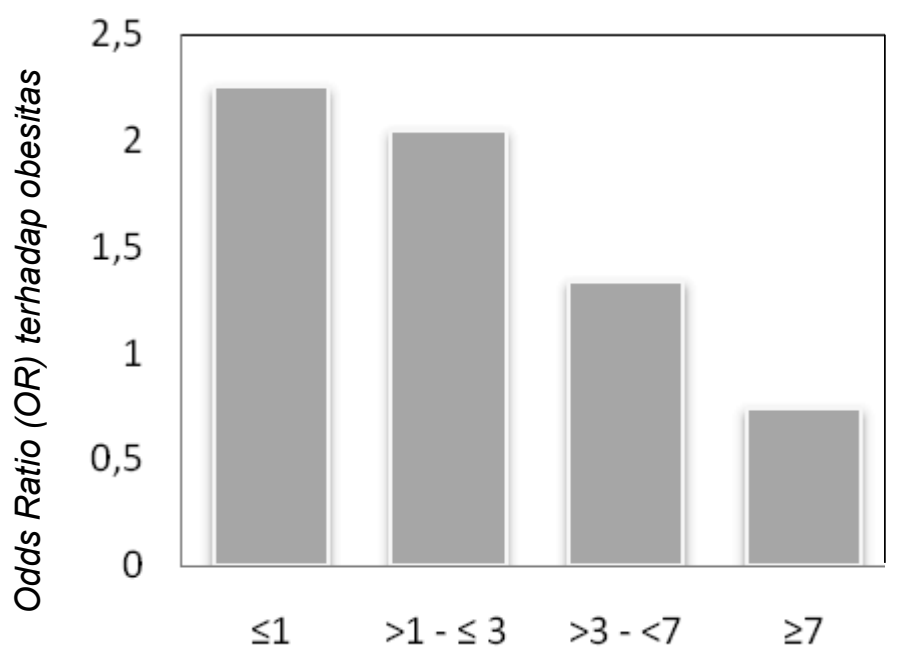

Frekuensi konsumsi sayur (kali/minggu)

Gambar 2. Dosis respon frekuensi konsumsi sayur terhadap kejadian obesitas pada anak obes dan tidak obes di Kota Yogyakarta dan Kabupaten Bantul

pada anak SD obes dan tidak obes di Kota Yogyakarta dan Kabupaten Bantul yang ditunjukkan dengan nilai OR. Hasil penelitian menunjukkan nilai OR semakin besar jika frekuensi konsumsi buah dan sayur semakin jarang dan nilai OR makin kecil jika frekuensi konsumsinya semakin sering. Konsumsi buah dan sayur kurang dari sama dengan $1 \mathrm{kali} / \mathrm{ming} g \mathrm{u}$, antara 1 sampai $3 \mathrm{kali} /$ minggu, dan antara 3 sampai $<7$ kali/minggu merupakan faktor risiko obesitas, sedangkan konsumsi buah $\geq 7$ kali/minggu merupakan faktor protektif dari terjadinya obesitas $(\mathrm{OR}=0,69)$, begitu juga dengan konsumsi sayur $\geq 7 \mathrm{kali} /$ minggu merupakan faktor protektif dari terjadinya obesitas $(\mathrm{OR}=0,74)$.

\section{BAHASAN}

Karakteristik usia anak sekolah dasar pada penelitian ini antara 6 hingga 12 tahun. Anak kemudian dikelompokan menjadi 6-9 tahun dan 10-12 tahun. Hasil analisis menunjukkan tidak ada perbedaan yang signifikan antarkelompok usia anak tersebut (Tabel 7). Meskipun demikian, dari beberapa penelitian banyak dijumpai peningkatan obesitas seiring bertambahnya usia (2).

Berbeda dengan jenis kelamin yang menunjukkan adanya perbedaan yang signifikan antara jenis kelamin laki-laki dan perempuan. Subjek penelitian ini lebih didominasi anak dengan jenis kelamin laki-laki (Tabel 1). Hasil uji bivariat menunjukkan bahwa anak lakilaki memilki risiko mengalami obesitas sebesar 1,71 kali dibandingkan dengan anak perempuan (Tabel 7). Penelitian ini sejalan dengan penelitian pada remaja usia 16-18 tahun di Brazil yang menunjukkan bahwa laki-laki lebih berisiko menjadi obes sebesar 2,27 kali dibandingkan dengan anak perempuan (9). Begitupula dengan hasil penelitian pada anak usia 5-15 tahun di Indonesia yang menunjukkan bahwa anak laki-laki memilki risiko obesitas sebesar 1,41 kali (1). Hasil penelitian di Kota Ho Chi Minh, Vietnam menunjukkan hal yang sama, remaja lakilaki berisiko 3,1 kali lebih besar menjadi overweight dan obesitas dibandingkan dengan remaja perempuan (14). Pada remaja laki-laki yang diketahui memilki IMT tinggi cenderung menghabiskan waktu duduk bermain games, memilki total screen time, dan asupan kalori lebih banyak jika dibandingkan dengan perempuan (15). Hal ini sesuai dengan sebuah penelitian yang menyebutkan bahwa anak laki-laki usia 7-9 tahun di Portugis bermain game elektronik lebih dari 2 jam sebanyak $67,6 \%$, sedangkan anak perempuan hanya $32,1 \%$, begitu juga dengan durasi menonton TV dan penggunaan komputer lebih dari 1 jam persentase lebih tinggi pada anak laki-laki dibanding dengan anak perempuan (16).

Status sosial ekonomi keluarga di Palembang berhubungan dengan kejadian obesitas dan merupakan faktor risiko terhadap kejadian obesitas pada remaja. Status ekonomi keluarga tinggi ini dihitung berdasarkan median tingkat pengeluaran yang mempunyai risiko obesitas 3,6 kali lebih tinggi dibandingkan dengan status ekonomi rendah (17). Di India, obesitas juga lebih banyak ditemukan pada kelompok dengan taraf hidup yang lebih tinggi (2). Namun demikian, pada hasil penelitian ini, status sosial ekonomi yang ditunjukkan dengan variabel pendidikan, pekerjaan, dan pengeluaran rumah tangga tidak terdapat perbedaan yang signifikan secara statistik $(p>0,05)$ antara anak SD yang obes dan tidak obes (Tabel 7). Beberapa hasil penelitian lainnya juga menunjukkan bahwa ternyata bukan hanya status ekonomi yang tinggi saja yang mendukung terjadinya obesitas pada anak 
(18), tetapi status ekonomi yang rendah juga dapat diduga meningkatkan kemungkinan terjadinya obesitas, seperti halnya banyak terjadi di negara Barat, yang mana prevalensi obesitas lebih sering terjadi pada kelompok berstatus sosial ekonomi rendah (2).

Persentase jumlah ayah dan ibu yang bekerja cenderung lebih banyak daripada ayah dan ibu yang tidak bekerja, baik pada anak obes maupun pada anak tidak obes (Tabel 1). Menurut sebuah penelitian pada remaja di Palembang menunjukkan hasil bahwa remaja dengan ibu yang bekerja bukan merupakan faktor risiko obesitas $(\mathrm{OR}=0,63)$ melainkan sebagai faktor protektif (17), sedangkan pada penelitian ini pekerjaan ibu tetap merupakan faktor risiko obesitas $(O R=1,18)$, meskipun secara statistik tidak signifikan $(p>0,05)$ (Tabel 7). Menurut penelitian di Arab Saudi, ibu yang bekerja berisiko 1,85 kali anaknya menjadi obes jika dibandingkan dengan ibu yang tidak bekerja $(p<0,05)(19)$. Ibu selaku pengasuh bertanggungjawab terhadap makanan anaknya. Ketersediaan makanan dalam keluarga di rumah akan lebih terproteksi dari terjadinya obesitas pada anak. Beberapa studi menemukan bahwa intensitas ibu yang bekerja berhubungan dengan kejadian obesitas dan overweight anaknya, tetapi hal ini hanya ditemukan pada keluarga dengan sosial ekonomi yang tinggi. Di beberapa subpopulasi, pekerjaan ibu bukan muncul sebagai faktor risiko obesitas dan terdapat hubungan yang kurang antara durasi jam kerja ibu dengan kejadian obesitas (20).

Pengeluaran per kapita hasilnya menunjukkan hubungan yang positif secara signifikan dengan kejadian obesitas $(p<0,05)$. Pengeluaran per kapita paralel dengan pendapatan (21). Pengeluaran rumah tangga serta rendahnya tingkat pendidikan berkaitan dengan meningkatnya angka obesitas pada anak. Orang tua dengan tingkat pendidikan yang rendah cenderung membiarkan anaknya mengkonsumsi makanan yang kaya kalori sehingga masalah kesehatan anaknya menjadi terabaikan (22), sedangkan tingkat pendidikan orangtua yang tinggi diduga akan mempunyai sikap, pengetahuan, dan perilaku yang lebih baik dalam pola asuh untuk makanan anaknya (23). Hasil uji statistik pada penelitian ini menunjukkan bahwa pendidikan ibu dan ayah tidak berhubungan dengan obesitas anaknya $(p>0,05)$. Ibu dan ayah yang memiliki pendidikan rendah bukan merupakan faktor risiko obesitas anaknya $(O R=0,79)$ melainkan sebagai faktor protektif. Persentase jumlah ibu dan ayah yang berpendidikan tinggi dan pengeluaran ( $\geq$ Rp. 1000.000) cenderung lebih banyak daripada yang berpendidikan dan pengeluran rumah tangga lebih rendah, baik pada anak obes maupun tidak obes (Tabel 7).

Hasil uji statistik nilai rata-rata asupan zat gizi antara anak SD obes dan tidak obes di Kota Yogyakarta dan Kabupaten Bantul terdapat perbedaan yang signifikan $(p<0,05)$ pada asupan energi, lemak, karbohidrat.
Rata-rata asupan energi anak SD obes sebesar 2.199.55 $\pm 758.37 \mathrm{kkal} / \mathrm{hari}$ dan anak SD tidak obes sebesar 2.000,01 $\pm 631,208 \mathrm{kkal} /$ hari (Tabel 2). Secara keseluruhan, rata-rata dari total asupan makanan anak SD yang obes cenderung mengkonsumsi energi lebih tinggi daripada anak tidak obes. Asupan energi anak obes melebihi Angka Kecukupan Gizi (AKG) rata-rata yang dianjurkan (per orang/hari) (Tabel 2). Kebutuhan energi umur 6 tahun berturut-turut sebesar 1.550 kkal, kemudian anak memasuki umur 7-9 tahun menjadi $1.800 \mathrm{kkal}$ dan pada umur 10-12 tahun kebutuhan energi meningkat lagi menjadi $2.050 \mathrm{kkal}(8,24)$. Asupan energi total kemudian dikategorikan menjadi tinggi energi jika lebih dari $110 \%$ AKG dan asupan energi kurang jika kurang dari 110\% AKG. Hasil uji bivariat menunjukkan bahwa asupan energi tinggi lebih berisiko menjadi obesitas sebesar 1,62 kali dibandingkan dengan asupan energi cukup (Tabel 7). Hasil penelitian ini sejalan dengan penelitian pada remaja SLTP berusia 10-15 tahun di Kota Yogyakarta dan Kabupaten Bantul yang menunjukkan rata-rata asupan energi total di Kota Yogyakarta pada kelompok kasus sebesar 2.818,32 $\pm 618,05 \mathrm{kkal} / \mathrm{hari}$ dan kontrol sebesar 2.210,42 $\pm 329,81$ $\mathrm{kkal} /$ hari, sedangkan rata-rata asupan energi di Kabupaten Bantul sebesar 2.416,99 $\pm 673,52 \mathrm{kkal} /$ hari, dan kontrol sebesar 1.778,09 $\pm 312,03 \mathrm{kkal} /$ hari, dengan hasil uji statistik menunjukkan adanya hubungan antara asupan energi total dengan kejadian obesitas pada remaja SLTP (25).

Tingginya asupan energi dari makanan yang dikonsumsi kemungkinan disebabkan konsumsi makanan cepat saji (makanan modern), seperti fast food dan junk food yang didefinisikan makanan dengan nilai gizi yang rendah, misalnya Chiki, Chesse ball, dan lainnya. Karakteristik fast food mengandung tinggi kalori, tinggi lemak, tinggi gula dan garam (26). Tingginya asupan ini disertai ketidakseimbangan pengeluaran energi dengan aktivitas fisik maka dapat menyebabkan penimbunan lemak dalam tubuh (24).

Hasil penelitian ini menunjukkan rata-rata asupan rerata serat total pada anak SD yang obes lebih rendah jika dibandingkan dengan asupan serat pada anak SD yang tidak obes, berturut-turut $13,47 \pm 20,61 \mathrm{gr} /$ hari dan $14,14 \pm 10,94 \mathrm{gr} /$ hari (Tabel 2). Rata-rata asupan serat total ini masih kurang dari anjuran kandungan serat per harinya sebesar 20-30 gram (6). Rata-rata asupan serat dari buah dan sayur menunjukkan hasil yang berbeda signifikan antara anak SD obes dan tidak obes $(p<0,05)$. Asupan serat dari buah dan sayur pada anak obes lebih sedikit jika dibandingkan dengan anak SD obes (Tabel 3).

Serat memberikan pengaruh yang amat besar terhadap fisiologis saluran pencernaan, karena makanan berserat sukar dicerna (27). Dengan adanya serat pangan, orang tersebut akan mengunyah lebih lama, sehingga akan menstimulir sekresi saliva (air liur) dan cairan lambung lebih 
banyak. Sekresi yang berlebihan ini akan menyebabkan perut merasa kenyang (28). Serat larut (soluble fiber) yang banyak terdapat dalam buah dan sayur, seperti pektin dan beberapa hemiselulosa mempunyai kemampuan menahan air dan dapat membentuk cairan kental dalam saluran pencernaan. Makanan kaya akan serat membutuhkan waktu dicerna lebih lama dalam lambung, kemudian serat akan menarik air dan memberi rasa kenyang lebih lama serta mencegah untuk mengkonsumsi makanan lebih banyak. Makanan dengan kandungan serat kasar yang tinggi biasanya mengandung kalori, kadar gula, dan kadar lemak yang rendah yang dapat mengurangi terjadinya obesitas. Selain itu, dengan adanya serat pangan maka penyerapan zat-zat gizi (pati, gula, protein, lemak) akan dihalangi $(29,30)$.

Serat terdapat dalam segala macam struktur tanaman, seperti berada di dinding sel sel akar, batang, daun, biji, dan buah, sehingga sumber serat dapat diperoleh dari serealia yang utuh (biji-bijian), sayuran, maupun buah. Buah dan sayuran lebih sering dikonsumsi masyarakat Indonesia dibandingkan dengan serealia yang utuh (28).

Hasil analisis bivariat dengan menggunakan regresi logistik menunjukkan ada perbedaan yang signifikan pada variabel frekuensi konsumsi buah dan frekuensi konsumsi sayur antara kasus, yaitu anak sekolah dasar yang obes dan kontrol, anak sekolah dasar yang tidak obes $(p<0,05)$. Anak SD yang jarang konsumsi buah ( $<7$ kali/minggu) memiliki peluang untuk menjadi obes sebesar 1,98 kali. Anak SD dengan frekuensi konsumsi sayur jarang ( $<7 \mathrm{kali} /$ minggu) mempunyai peluang 2,24 kali menjadi obes. Pada anak dengan jumlah konsumsi buah dan sayur kurang dari 5 porsi/ hari mempunyai peluang berisiko menjadi obes sebesar 3,94 jika dibandingkan dengan anak yang konsumsi buah dan sayurnya lebih dari 5 porsi/hari (Tabel 7 ).

Hasil analisis multivariat setelah dikontrol dengan variabel jenis kelamin dan persentase asupan energi berdasar AKG, maka anak yang frekuensi konsumsi buah ( $<7 \mathrm{kali} /$ minggu) berisiko 2,24 kali untuk terjadinya obesitas. Anak yang jarang mengkonsumsi sayur ( $<7$ kali/ minggu) berisiko 2,52 kali untuk terjadinya obesitas jika dibandingkan dengan anak SD yang sering konsumsi sayur ( $\geq 7 \mathrm{kali} /$ minggu) (Tabel 8 ).

Hasil ini sesuai dengan penelitian sebelumnya di Brazil yang menunjukkan bahwa dengan konsumsi buah $\geq 5$ kali/minggu akan terproteksi 1,76 kali dari terjadinya overweight dan obesitas (8). Penelitian ini didukung hasil penelitian lainnya di Arab Saudi yang menunjukkan bahwa anak yang mengkonsumsi buah $<5 \mathrm{kali} /$ minggu berisiko 1,6 kali untuk terjadinya obesitas dibandingkan dengan anak yang frekuensi konsumsi buah 5-6 kali/minggu, serta anak yang mengkonsumsi sayur $<5 \mathrm{kali} /$ minggu berisiko 1,8 kali untuk terjadinya obesitas dibandingkan dengan anak yang frekuensi konsumsi sayur 5-6 kali/minggu
(19). Begitu juga sebuah penelitian pada orang dewasa di Brazil dengan mengkonsumsi buah kurang dari 1 kali sehari dapat berisiko 1,84 kali lebih besar untuk terjadinya overweight dan obesitas (9). Hasil penelitian yang sama juga ditunjukkan di Kota Ho Chi Minh, Vietnam yang menunjukkan bahwa remaja yang mengkonsumsi buah dan sayur secara teratur dapat terproteksi dari terjadinya obesitas sebesar 3,3 kali, sedangkan jika konsumsi buah saja dengan frekuensi sering dapat terproteksi sebesar 2,5 kali dan jika konsumsi sayur saja secara sering setiap hari dapat terproteksi sebesar 2 kali (14).

Beberapa penelitian eksperimental pun dilakukan di antaranya penelitian dengan intervensi pada dua kelompok perlakuan. Pada kelompok perlakuan, peningkatan konsumsi buah dan sayur selama 1 tahun ternyata dapat menurunkan persentasi overweight daripada kelompok yang diberi perlakuan penurunan asupan lemak dan gula (31). Selanjutnya, terdapat penelitian prospective cohort yang diikuti selama 12 tahun pada perawat perempuan berusia 38-63 tahun yang menghasilkan kesimpulan bahwa peningkatan asupan konsumsi buah dan sayur dapat mengurangi risiko jangka panjang terhadap obesitas dan peningkatan berat (32). Hasil penelitian selama 5 tahun pada populasi Mediterania menunjukkan hubungan terbalik antara konsumsi buah atau sayur dengan peningkatan berat badan yang dibuktikan dengan tingginya asupan serat total (33).

Jumlah rata-rata konsumsi buah anak usia 7-9 tahun dan 10-12 tahun sebaiknya sebanyak 3 porsi, sedangkan jumlah rata-rata konsumsi sayur anak usia 7-9 tahun sebanyak 3 porsi dan 10-12 tahun sebanyak 4 porsi, yang setara dengan 200-300 gram buah dan sayur (24). Hal ini sesuai dengan rekomendasi dari WHO (World Health Organization) dan FAO (Food and Agriculture Organization) untuk mengkonsumsi buah dan sayur 400 gram setiap harinya agar terhindar dari obesitas (12) atau setara dengan 5 porsi/hari (13). Pada penelitian ini, anak SD yang mengkonsumsi buah dan sayur kurang dari 5 porsi/hari berisiko menjadi obes sebesar 4,59 kali dibandingkan dengan anak SD yang mengkonsumsi buah dan sayur lebih dari 5 porsi/hari (Tabel 8). Asupan makanan berbasis tanaman (plant foods) spesifik secara rutin dapat mencegah overweight pada anak-anak dan remaja (34), karena diet berbasis tanaman (plant foods) ini rendah densitas energinya dan tinggi karbohidrat kompleks, serat, dan air, sehingga dapat meningkatkan rasa kekenyangan dan dapat berefek pengurangan asupan makanan lain (makan besar) sehingga dapat mengontrol berat badan (35).

Rata-rata jumlah total konsumsi buah dan sayur berbeda signifikan antara kasus dengan kontrol $(p<0,05)$. $\mathrm{Hal}$ ini berarti jumlah konsumsi buah dan sayur pada anak obes lebih sedikit daripada anak tidak obes, berturut-turut sebesar 1,96 $\pm 1,62$ porsi/hari dan 2,89 $\pm 2,54$ porsi/hari (Tabel 6) yang menunjukkan bahwa baik pada anak obes 
maupun tidak obes banyak yang jumlah konsumsi buah dan sayurnya masih rendah dan kurang dari anjuran yaitu 5-7 porsi/hari (2,24). Di antara total 488 sampel anak, terdapat 447 anak obes dan tidak obes yang jumlah konsumsi buah dan sayur kurang dari 5 porsi/hari, sedangkan 41 anak sisanya memiliki konsumsi buah dan sayur lebih dari sama dengan 5 porsi/hari. Dengan demikian dapat diketahui bahwa terdapat $91,59 \%$ anak yang mengkonsumsi buah dan sayur kurang dari 5 porsi/hari (Tabel 7). Hasil penelitian ini sesuai dengan penelitian lain yang menggunakan sumber data sekunder Riskesdas tahun 2007 dan menunjukkan sekitar 90\% anak berusia 5-15 tahun di Indonesia mengkonsumsi sayur dan buah kurang dari 3 porsi/hari (1). Berdasarkan Laporan Riskesdas tahun 2007, di Indonesia perilaku kurang konsumsi buah dan sayur masih tinggi. Prevalensi kurang konsumsi buah dan sayur ( $<5$ porsi per hari) penduduk Indonesia yang berumur di atas 10 tahun mencapai 93\%, sedangkan di Provinsi DI Yogyakarta sebanyak 86,1\% (4).

Ketersediaan pangan (food availability) dalam jumlah cukup dapat diperoleh dari produksi dalam negeri maupun impor (3). Indonesia merupakan wilayah tropis yang kaya akan keanekaragaman hayati termasuk berbagai jenis buah-buahan (36). Jenis sayuran yang ditemukan di pasar-pasar jauh lebih banyak di daerah tropis seperti di Indonesia daripada di negara-negara beriklim sedang. Lebih dari 100 jenis (spesies) tanaman yang dapat dibudidayakan, sedangkan 50 jenis lagi dapat diperoleh dari pertumbuhan liar (37). Hanya saja ternyata berdasarkan hasil kajian Litbang Departemen Pertanian bulan Maret 2013, tingkat konsumsi buah per kapita hanya 34,55 kg/tahun, sedangkan tingkat konsumsi buah dan sayur di negara tetangga seperti Vietnam dan Singapura telah mencapai lebih dari 100 kg/tahun. Padahal FAO merekomendasikan $73 \mathrm{~kg} / \mathrm{kapita} / \mathrm{tahun}$ (38).

Akses pangan adalah kemampuan rumah tangga atau individu sebagai sumber daya yang dimilikinya untuk memperoleh pangan tersebut. Akses rumah tangga dan individu terdiri dari akses ekonomi, fisik, dan sosial. Akses ekonomi tergantung dari pendapatan, pekerjaan, dan harga (3). Orangtua bertanggung jawab atas ketersediaan dan kemudahan mengakses terhadap makanan di rumah terutama anaknya, termasuk buah dan sayur (8). Pada penelitian ini, hasil analisis stratifikasi menunjukkan bahwa hubungan antara frekuensi dan jumlah konsumsi buah dan sayur dengan obesitas tidak dipengaruhi oleh variabel sosial ekonomi keluarga yang sebelumnya diduga merupakan faktor pengganggu (confounding factor) atau efek modifikasi. Kemakmuran keluarga secara positif berhubungan dengan konsumsi buah, tetapi tidak dengan konsumsi sayur (23). Berdasarkan Laporan Riskesdas tahun 2007, semakin tinggi tingkat pengeluaran per kapita per bulan, semakin tinggi konsumsi buah dan sayur
(4). Hal ini terjadi kemungkinan karena peningkatan status ekonomi keluarga dapat meningkatkan daya beli terhadap makanan, baik jumlah maupun macamnya (18). Hal ini sejalan dengan sebuah penelitian yang dilakukan oleh Committee on Nutrition di Inggris bahwa anak-anak yang berasal dari keluarga yang status ekonominya lebih rendah mengkonsumsi buah dan sayuran lebih sedikit dan memiliki asupan kalori dan lemak total yang lebih banyak. Pendapatan keluarga yang lebih rendah dilaporkan mengalami kesulitan dalam mengakses makanan sehat, terutama sayur dan buah (19), sementara berdasarkan Riskesdas tahun 2007, semakin tinggi tingkat pendidikan semakin baik konsumsi buah dan sayur (4).

Akses fisik menyangkut isolasi daerah (sarana dan distribusi). Pasar menjadi pusat distribusi yang menampung hasil produksi petani maupun produk impor, sementara dari segi akses sosial menyangkut preferensi pangan (3). Dalam hal ini adalah preferensi konsumsi buah dan sayur. Sebuah penelitian di China pada usia prasekolah menunjukkan tidak ada perbedaan yang signifikan antara preferensi sayur dan buah antara kasus anak obes dengan kontrol dan preferensi ini bukan merupakan faktor risiko obesitas (39).

\section{KESIMPULAN DAN SARAN}

Anak SD yang obes lebih jarang dan lebih sedikit mengkonsumsi buah dan sayur dibandingkan dengan anak SD yang tidak obes di Kota Yogyakarta dan Kabupaten Bantul. Frekuensi jarang konsumsi buah dan sayur ( $<7$ kali/minggu) merupakan salah satu faktor risiko obesitas, selain jenis kelamin dan asupan energi tinggi pada anak SD di Kota Yogyakarta dan Kabupaten Bantul. Tidak terdapat perbedaan asupan serat total antara anak SD yang obes dan tidak obes, sedangkan asupan serat dari buah dan sayur berbeda antara anak SD obes dan tidak obes di Kota Yogyakarta dan Kabupaten Bantul.

Berdasarkan kesimpulan tersebut, disarankan perlu adanya pendidikan ilmu gizi dan kesehatan bagi anak sekolah dasar, terutama tentang pemilihan jenis dan jumlah makanan yang sesuai kebutuhannya, misalnya diawali program penyuluhan manfaat konsumsi sayur dan buah pada guru sekolah dasar serta peningkatan pengawasan makanan di kantin sekolah. Program tersebut dirancang sebaik mungkin oleh Dinas Kesehatan bekerja sama dengan Dinas Pendidikan di Kota Yogyakarta dan Kabupaten Bantul. Selain itu, perlunya perhatian orang tua di rumah dalam pemilihan makanan untuk anak dan diharapkan adanya peningkatan konsumsi buah dan sayur pada anak. Perlunya penelitian serupa atau lebih lanjut dengan metode cohort prospektif, sehingga dengan cara ini bias yang diakibatkan karena subjek (bias ingatan) dapat dihindari. 


\section{RUJUKAN}

1. Depkes RI. Riset Kesehatan Dasar 2007. Jakarta: Departemen Kesehatan RI; 2008.

2. Kemenkes. Riset Kesehatan Dasar. Jakarta: Departemen Kesehatan RI; 2010.

3. Sartika RAD. Faktor risiko obesitas pada anak obesitas 5-15 tahun di Indonesia. Makara kesehatan 2011;15(1):37-43.

4. Barasi ME. At a Glance IImu Gizi. A. Safitri \& R. Astikawati, eds. Jakarta: Penerbit Erlangga; 2011.

5. Adriani M, Wirjatmadi B. Pengantar Gizi Masyarakat. Jakarta: Kencana Prenada Media Grup; 2012.

6. Almatsier S. Prinsip Dasar Ilmu Gizi. Jakarta: PT Gramedia Pustaka Utama; 2004.

7. Kurniasih D, H Hilmansyah, MP Astuti, S Imam. Sehat \& Bugar Berkat Gizi Seimbang. Soekirman, N. Afriansyah, \& J. Erikania, eds. Jakarta: PT Gramedia; 2010.

8. Neutzling, Marilda BJ, August AC, Taddei DP, Gigante. Risk factors of obesity among Brazilian adolescents : a case - control study risk factors of obesity among Brazilian adolescents : a case - control study. Public Health Nutr 2003;6(8):743-9.

9. Menezes IHCF, Neutzling M, Borges, Taddei, JADAC. Risk factors for overweight and obesity in adolescents of a Brazilian university : a case-control study. Nutr Hosp 2009; 24(1):17-24.

10. Sullivan KM, May S, and Maberly G. Urinary iodine assessment:a manual on survey and laboratory methods, 2nd ed. UNICEF, PAMM; 2000.

11. WHO. WHO growth reference data for 5-19 years. Available from: http://www.who.int/growthref/ en/.2012.

12. WHO. Promoting fruit and vegetable consumption around the world. Available from: http://www.who.int/ dietphysicalactivity/fruit/en/index.html. 2002.

13. Ness AR, Powles JW. Fruit and Vegetables, and Cardiovascular Disease : A Review. Int J Epidemiol 1997;26(1):1-13.

14. Hong TK, Nguyen HHD, Trang MJ, Dibley DW, Sibbitt, Phan NT et al. Factors associated with adolescent overweight/obesity in Ho Chi Minh City. Int J Pediat Obes 2010;5:396-403.

15. Goldfield GS, Kenny GP, Hadjiyannakis S, Phillips P, Alberga AS, TJ Saunders, et al. Video game playing is independently associated with blood pressure and lipids in overweight and obese adolescents. PLoS ONE 2011;6(11):e26643.

16. Carvalhal MM, MC Padez, PA Moreira, VM Rosado. Overweight and obesity related to activities Portuguese children 7 - 9 years. Eur J Public Health 2006,17(1):42-6.

17. Podojoyo, Hadi H, Huriyati E. Pola konsumsi makanan di luar rumah sebagai faktor risiko terjadinya obesitas pada remaja smp di kota palembang. Jurnal Gizi Klinik Indonesia 2006;3(2):46-55.

18. Yussac MAA, A Cahyadi, AC Putri, AS Dewi, A Khomaini, S Bardosono, et al. Prevalensi obesitas pada anak usia 4-6 tahun dan hubungannya dengan asupan serta pola makan. Majalah Kedokteran Indonesia 2007;57(2):47-53.

19. Amin, Tarek TK, Ali IAS, Ayub A. Overweight and obesity and their association with dietary habits, and sociodemographic characteristics among male primary school children in Al-Hassa, Kingdom of Saudi Arabia. Indian J Community Med 2008;33(3):172-81.

20. Maher J, Fraser SM, Wright J. Framing the mother: childhood obesity, maternal responsibility and care. J Gender Stud 2010;19(3):233-47.

21. Sugianti E, Hardinsyah, N Afriansyah. Faktor risiko obesitas sentral pada orang dewasa di DKI Jakarta: analisis lanjut data riskesdas 2007. Gizi Indonesia 2008;32(2):105-18.

22. Naamsyah D. Pada anak: akibat dan penanganannya. Majalah Kedokteran Damianus 2008;7(1):55-63.

23. Mccormack GR, P Hawe, R Perry, A Blackstaffe. Associations between familial affluence and obesity risk behaviours among children. J Pediatr Child Health 2011;16(1):19-24.

24. Imatsier S, Soetardjo S, Soekarti M. Gizi Seimbang Dalam Daur Kehidupan. Jakarta: PT Gramedia Pustaka Utama; 2011.

25. Medawati A, Hadi H, Pramantara IDP. Hubungan antara asupan energi, asupan lemak, dan obesitas pada remaja SLTP di Kota Yogyakarta dan di Kabupaten Bantul. Jurnal Gizi Klinik Indonesia 2005;1(3).

26. Budiman $\mathrm{H}$. Fast food-suatu masalah keseimbangan makanan. Majalah Kedokteran Atma Jaya 2004;3(1):7780.

27. Beck, Mary E. Ilmu Gizi dan Diet Hubungannya dengan Penyakit-Penyakit untuk Perawat dan Dokter. Yogyakarta: Penerbit ANDI; 2011.

28. Muchtadi D. Sayuran sebagai sumber serat pangan untuk mencegah timbulnya penyakit degeneratif. Jurnal Teknologi dan Industri Pangan 2001;XII(1):61-71.

29. Santoso A. Serat pangan (dietary fiber) dan manfaatnya bagi kesehatan. Magistra 2011;23(75):35-40.

30. Moehyi S. 30 Makanan Super Pencegah dan Penyembuh Penyakit Berbahaya Hasil Penelitian Ahli Gizi Dunia. Penerbit Papas Sinar Sinanti; 2012.

31. Epstein LH, CC Gordy, HA Raynor, M Beddome, CK Kilanowski, R Paluch. Increasing fruit and vegetable intake and decreasing fat and sugar intake in families at risk for childhood obesity. Obes Res 2001;9(3):171-8.

32. He K, FB Hu, GA Colditz, JE Manson, WC Willett, S Liu. Changes in intake of fruits and vegetables in relation to risk of obesity and weight gain among middle-aged women. Int J Obes 2004;28:1569-74. 
33. Bes-rastrollo M, MA Martinez-Gonzalez, A SanchezVillegas, C de la fuente Arrillaga, JA. Martinez. Association of fiber intake and fruit / vegetable consumption with weight gain in a Mediterranean population. Nutr 2006;22:504-11.

34. Matthews VL, M Wien, Joan S. The risk of child and adolescent overweight is related to types of food consumed. Nutr J 2011;10:71.

35. Sabate J, Michelle W. Vegetarian diets and childhood obesity prevention. Am J Clin Nutr 2010;91:1525S-9S.

36. Ashari S. Meningkatkan Keunggulan Bebuahan Tropis Indonesia. Yogyakarta: Penerbit ANDI; 2009.
37. Williams CN, Uzo JO, Peregrine WTH. Produksi Sayuran di Daerah Tropika G. Tjitrosoepomo, ed., Yogyakarta: Gadjah Mada University Press; 1993.

38. Abdurrahman MN. Konsumsi buah dan sayur di indonesia ketinggalan dari negara tetangga. Available from: m.detik.com/helath/read/2013/06/28/190119 /2287595/763/konsumsi-buah-sayur-di-Indonesiaketinggalan-dari-negara-tetangga.

39. He Q, ZY Ding, DYT Fong, J Karlberg. Risk factor of obesity in preschool children in China: a populationbased case-control study. Int J Obes 2000;24:152836. 